\title{
Are changes in urinary parameters during pregnancy clinically significant?
}

\author{
Sefa Resim • Hasan Cetin Ekerbicer • Gurkan Kiran • \\ Metin Kilinc
}

Published online: 5 September 2006

(C) Springer-Verlag 2006

\section{Erratum to: Urol Res 34:244-248 DOI 10.1007/s00240-006-0051-7}

The first names and the family names of the authors were reversed. The list of authors should read: Sefa Resim, Hasan Cetin Ekerbicer, Gurkan Kiran, Metin Kilinc.

The contact information should read:
S. Resim
Department of Urology, KSU Medical School,
Kahramanmaras, Turkey

H. C. Ekerbicer

Department of Public Health, KSU Medical School, Kahramanmaras, Turkey

The online version of the original article can be found at http:// dx.doi.org/10.1007/s00240-006-0051-7.

\footnotetext{
S. Resim

Department of Urology, KSU Medical School,

Kahramanmaras, Turkey

H. C. Ekerbicer

Department of Public Health, KSU Medical School,

Kahramanmaras, Turkey

G. Kiran

Department of Obstetrics and Gynecology,

KSU Medical School, Kahramanmaras, Turkey

M. Kilinc

Department of Biochemistry, KSU Medical School,

Kahramanmaras, Turkey

S. Resim $(\bowtie)$

P.K. 157, 46002 Kahramanmaras, Turkey

e-mail: safaresim@ksu.edu.tr
}

\section{G. Kiran}

Department of Obstetrics and Gynecology, KSU Medical School, Kahramanmaras, Turkey

M. Kilinc

Department of Biochemistry, KSU Medical School, Kahramanmaras, Turkey

S. Resim (必)

P.K. 157, 46002 Kahramanmaras, Turkey

E-mail: safaresim@ksu.edu.tr

Tel.: +90-344-2212337

Fax: +90-344-2212371 